\title{
Antioxidant and Antimicrobial Activity of Solvent Fractions of Calpurnia aurea (Ait.) Benth. (Fabaceae)
}

\author{
Dessie Belay ${ }^{1,2}$ \\ Ambaye Kenubih (iD ${ }^{2}$ \\ Mohammed Yesuf ${ }^{2}$ \\ Elias Kebede ${ }^{3}$ \\ Muluken Yayeh ${ }^{2}$ \\ Mastewal Birhan (iD) ${ }^{2}$ \\ 'Livestock Promotion Sector, Belessa \\ District Agricultural Office, Gondar, \\ Amhara, Ethiopia; ${ }^{2}$ Veterinary Para- \\ Clinical Studies, University of Gondar, \\ College of Veterinary Medicine and \\ Animal Sciences, Gondar, Amhara, \\ Ethiopia; ${ }^{3}$ Veterinary Pharmacy, \\ University of Gondar, College of \\ Veterinary Medicine and Animal Sciences, \\ Gondar, Amhara, Ethiopia
}

Background: Calpurnia aurea (Ait.) Benth. leaves are used to treat different diseases like ectoparasite infestation, diarrhea, sores, anthrax, fevers, pain, and snake venom. The leaves of Calpurnia aurea were first extracted by methanol and further fractionated with the help of n-hexane, dichloromethane and ethyl acetate with increasing polarity.

Methods: The antibacterial activities of the fractions were evaluated against disease causing bacteria using agar well diffusion. The minimum inhibitory concentrations (MIC) of the fractions were determined by the micro-broth dilution method using tetrazolium salt colorimetric assay. The antioxidant activities of the solvent fractions were determined by phosphomolbedum reduction assay, reducing power assay and hydroxyl radical scavenging activity. Results: The average MIC value of $C$. aurea fractions ranged from $1.95 \mathrm{mg} / \mathrm{mL}$ to $31.25 \mathrm{mg} /$ $\mathrm{mL}, 7.81 \mathrm{mg} / \mathrm{mL}$ to $31.25 \mathrm{mg} / \mathrm{mL}$ and $13.02 \mathrm{mg} / \mathrm{mL}$ to $62.5 \mathrm{mg} / \mathrm{mL}$, for ethyl acetate, dichloromethane and n-hexane fractions, respectively. The leaf extracts have a higher antioxidant effect, as shown in the phospho-molbedum reduction assay, reducing power and hydroxyl radical scavenging assay.

Conclusion: The ethyl acetate and dichloromethane fractions revealed significant antibacterial effects against the growth of pathogenic bacteria. However, the n-hexane fraction showed the least antibacterial effect against all of the test bacteria. Furthermore, the nhexane fractions of $C$. aurea showed higher antioxidant activity.

Keywords: antimicrobial, antioxidant, Calpurnia aurea, in vitro, solvent fractions

\section{Background}

Animal cultivation is a central feature of the jobs of more than $70 \%$ of Ethiopians. Approximately $90 \%$ of power generation in Ethiopia hinges on draft animals. Animals moreover offer the means of survival in terms of nourishment security within the nation. ${ }^{1}$

However, lacking veterinary wellbeing experts, rare and sporadic supply of veterinary drugs, the expense of gear and drugs, nonattendance of governmentbased animal wellbeing arrangements, counterproductive animal wellbeing arrangements and destitution are a few of the major factors making animals raisers in developing nations depend more on ethno-veterinary medication than cutting edge science. $^{2}$ In Ethiopia, even 'cutting edge' practices instigated as long ago as 1908 are not followed. Rather, ethno-veterinary practices have been honed to deal with animal afflictions. ${ }^{3}$

There is a long-established custom of knowing the medicinal properties of many plants that are used to cure human and livestock diseases. ${ }^{4}$ Nearly $90 \%$ of the livestock population in Ethiopia relies on traditional plant remedies as the major
Correspondence: Ambaye Kenubih Email ambayken@yahoo.com 
source of therapeutics. ${ }^{5}$ Over $95 \%$ of the materials that are traditionally used in prepared remedies are obtained from plants. The medicinal plants that are used as a common good are present in the markets to be used for fumigation, vermifuge, pain relief and treating sick animals. Among these, Echinops kebericho (Asteraceae) is widely sold in the market for fumigation of cattle. Other plants that have antimicrobial and wound healing properties are also commonly obtained in Ethiopian markets. ${ }^{6}$

Calpurnia aurea is among the major conventional plants utilized to treat distinctive afflictions and is broadly used throughout Ethiopia. ${ }^{7}$ C. aurea has a number of ethno-veterinary uses such as treating external parasites, ${ }^{8,9}$ helminthiasis, ${ }^{10,11}$ swelling of the nose in mules, sores and depression, rabies, parasitic leeches, snakebites, ${ }^{47,10,12,13}$ anthrax, ${ }^{14-16}$ and blackleg. ${ }^{16,17} \mathrm{~A}$ root concoction is used to stop bleeding after birth, ${ }^{18}$ and root extracts are used to treat bloody diarrhea, ${ }^{8,15}$ skin diseases, ${ }^{19}$ and stomach ache. $^{20}$

Phytochemical screening of crude ethanol and methanol leavf extracts of $C$. aurea exhibited the presence of cardiac glycosides, phytosteroids, flavonoids, alkaloids, phenols, and terpenoids. ${ }^{21-24}$ Deep chemical investigation of $C$. aurea leaves has shown a series of quinolizidine alkaloids and pyrrole carboxylic acid ester. ${ }^{25}$ Among these secondary metabolites, the quinolizine alkaloids have a molicidal effect. ${ }^{26}$ Calpurnia contains a large quantity of flavonoid content which has been reported to possess robust antioxidant properties. ${ }^{23,27}$ Therefore, this study aimed to determine the antimicrobial and antioxidant properties of different solvent fractions of $C$. aurea leaf extracts.

\section{Methods}

\section{Collection and Preparation of Plant Material}

Fresh and healthy leaves of $C$. aurea (Ait.) Benth. were collected from Tara-gedam forests, located in the Libo Kemkem District (South Gondar Zone) of Amhara Regional State, which is located at around $12^{\circ} 04.351^{\prime}$ $12^{\circ} 10.926^{\prime} \mathrm{N}$ and $37^{\circ} 44.266^{\prime}-37^{\circ} 50.057^{\prime} \mathrm{E}$. The leaves were identified in the University of Gondar, College of Natural and Computational Science in Botany department by an experienced botanist (Abiyu Enyew) and the voucher specimen (016AKWGU) was deposited for feature references. Then the leaves were rinsed thoroughly with tap water and dried in a dark place. The dried leaf materials were grinded by electric mill.

\section{Preparation of Plant Extracts}

Approximately $1 \mathrm{~kg}$ of dry powder leaves were macerated and extracted in $95 \%$ methanol (1:5) for $48 \mathrm{hrs}$ three times, then the crude extracts were filtered using Whatman filter paper No. 1 . The crude extracts were kept at $4{ }^{\circ} \mathrm{C}$ and all three extracts were mixed and subjected to evaporation by a rota-vaporizer (Buchi, England) set at $50^{\circ} \mathrm{C}$. Next, they were dried using a freeze drier (Ningbo, China). The crude extract was further fractionated a on separatory funnel by using nonpolar solvents (n-hexane followed by dichloromethane followed by ethyl acetate) for $4 \mathrm{hrs}$ three times and further subjected to evaporation by rota-vaporizer set at $50^{\circ} \mathrm{C}$. Finally, it was dried with a freeze drier.

\section{Phytochemical Screening of the Fractions}

Ethyl acetate, dichloromethane n-hexane fraction and crude methanol extracts of $C$. aurea leaves were screened for the presence of phenolic compounds, terpenoids, cardiac glycosides, alkaloids, saponins and tannins using standard phytochemical procedures as described by Ayoola et $\mathrm{al}^{28}$ and Farhan et al. ${ }^{29}$ Briefly, the following were appplied: the Salkowski test for terpenoids, the Liebermann-Burchard test for steroids, the frothing test for saponins, the ferric chloride test for tannins, the Keller-Killiani test for cardiac glycosides, the Dragendorff's and the Mayer's tests for alkaloids, and the ammonia test for detection of flavonoids.

\section{Bacterial Strains}

Test bacteria were the kind gift of the National Animal Health Diagnostic and Investigation Center (NAHDIC), Sebeta, Ethiopia and the Ethiopia Public Health Institute (EPHI), Addis Ababa, Ethiopia. This test was conducted using the following test bacterial strains: $S$. aureus (ATCC 29213), E. coli (ATCC 25922), E. faecalis (ATCC 29212), K. pneumonia (ATCC 700603), C. freundii (ATCC 43864), S. typhi (ATCC 6539), and E. coli clinical isolate.

\section{Inoculum Preparation}

The sterile nutrient agar plate was prepared and inoculated with standard pathogenic bacteria aseptically, and incubated for $24 \mathrm{hrs}$ at $37^{\circ} \mathrm{C}$. The bacterial suspension was then adjusted to obtain turbidity visually comparable to the prepared $0.5 \mathrm{McF}$ arland standards. The turbidity of the inoculum tube was adjusted to $0.5 \mathrm{McF}$ arland standard 
$\left(1 \times 10^{8} \mathrm{cfu} / \mathrm{mL}\right)$. The adjustment and comparison of the turbidity of the inoculum tube and that of the standard was performed by visual observation. ${ }^{23,30,31}$

\section{Antimicrobial Assay Agar Well Diffusion}

Agar well diffusion was conducted to screen antimicrobial activity of fractions. The standardized bacterial suspension was streaked uniformly on prepared sterile Muller Hinton Agar (MHA) plates, then five equally spaced wells were made with a sterile cork borer $(6 \mathrm{~mm}$ diameter). The labeled wells were filled with $100 \mu \mathrm{L}$ of $500 \mathrm{mg} / \mathrm{mL}, 250$ $\mathrm{mg} / \mathrm{mL}, 125 \mathrm{mg} / \mathrm{mL}$ and $62.5 \mathrm{mg} / \mathrm{mL}$ of each of the solvent fractions. $^{22}$ As well as the commercial antibiotic discs of ciprofloxacin, $0.005 \mathrm{mg} / \mathrm{disc}$ and gentamicin, $0.01 \mathrm{mg} / \mathrm{disc}$ was used as a positive control and $100 \mu \mathrm{L}$ of $5 \%$ dimethylsulphoxide (DMSO) was used as a negative control. Then, the plates were left undisturbed for about $30 \mathrm{~min}$ at room temperature. Next, it was incubated at $37^{\circ} \mathrm{C}$ for $24 \mathrm{hrs}$. The inhibition zone was measured using a digital caliper. Each test was performed three times for each plate and the means of inhibition zones were calculated for each fraction.

\section{Determination of Minimum Inhibitory Concentration} Under aseptic conditions, 96 well microtitre plates (Greiner Bio-One, Germany) were used for tetrazolium salt colorimetric assay. The first column of microtiter plate was filled with $100 \mu \mathrm{L}$ Mullen Hinton Broth (MHB). Then, $50 \mu \mathrm{L}$ of MHB was dispensed to the rest of wells, ${ }^{30,32}$ while the first column was filled with solution of fractions $(500 \mathrm{mg} / \mathrm{mL})$. A serial two-fold dilution of the solvent fraction was conducted from the second to the tenth rows. The bacterial suspension was prepared by diluting the $0.5 \mathrm{McFarland}$ standard turbidity equivalent bacterial suspensions $\left(1 \times 10^{8} \mathrm{cfu} / \mathrm{mL}\right)$ in the ratio of $1: 20$ in the respective broth to get a final concentration of approximately $5 \times 10^{6} \mathrm{cfu} / \mathrm{mL}^{33}$ Twenty microliters of diluted bacterial suspension was dispensed to each well except for those in the eleventh row (negative control). Each plate had a set of three controls. ${ }^{1}$ The eleventh column contained all solutions plus ceftriaxone as a positive control ${ }^{2}$ and the twelfth column with all solutions plus $100 \mu 15 \%$ dimethylsulphoxide (5\% DMSO) was used as negative control. Each plate was wrapped loosely with parafilm (American National $\mathrm{Can}^{\mathrm{TM}}$, Greenwich, USA) to prevent dehydration then incubated at $37^{\circ} \mathrm{C}$ for $24 \mathrm{hrs}$. After $24 \mathrm{hr}$ incubation at $37^{\circ} \mathrm{C}, 30 \mu \mathrm{L}$ of the aqueous solution of
$2.5 \mathrm{mg} / \mathrm{mL}$ of 2, 5-diphenyl tetrazolium chloride (UNI CHEM, India) was added and mixed in each well and further incubated for $30 \mathrm{~min}$. The lowest concentration of fraction at which no color change occurred was recorded as the MIC value and all tests were performed in triplicate for each bacterium. ${ }^{30}$

\section{Minimum Bactericidal Concentration}

This was determined by aseptically sub-culturing $5 \mu \mathrm{L}$ of the contents of wells from the MIC results for each pathogenic test bacterium to sterile plate counting agar ${ }^{34,35}$ and incubated at $37^{\circ} \mathrm{C}$ for $24 \mathrm{hrs}$. The lowest concentration of the fractions which showed no bacterial growth after incubation was observed for each triplicate and noted as the MBC. ${ }^{30}$

\section{Antioxidant Effect}

\section{Phosphomolybdenum Reduction Assay}

Phosphomolybdenum reduction potential of plant fractions was determined according to Snousi et al. ${ }^{36}$ Reagent was prepared by mixing $0.0499 \mathrm{~mL}$ ammonium molybdate (4mM), $0.588 \mathrm{~mL}$ sulpheric acid $(0.6 \mathrm{M})$, and $0.369 \mathrm{~mL}$ of monosodium phosphate $(28 \mathrm{mM})$. The assay mixture contained $100 \mu \mathrm{L}$ of plant fraction at different concentrations $(25,50$ and $100 \mu \mathrm{g} / \mathrm{mL})$ and $1 \mathrm{~mL}$ reagent solution. The mixture was incubated at $95^{\circ} \mathrm{C}$ for $90 \mathrm{~min}$. The absorbance of green complex was measured at $695 \mathrm{~nm}$. Ascorbic acid was used as a positive control. The result was represented in terms of the number of microgram equivalents of ascorbic acid per milligram of fractions.

\section{Reducing Power Assay}

The reducing power of $C$. aurea leaf fractions were determined according to the method previously described by Boulekbache-Makhlouf et al. ${ }^{37}$ Different concentrations of C. aurea leaf fractions $(25 \mu \mathrm{g} / \mathrm{mL}, 50 \mu \mathrm{g} / \mathrm{mL}$ and $100 \mu \mathrm{g} / \mathrm{mL})$ in $1 \mathrm{~mL}$ of distilled water were mixed with phosphate buffer $(2.5 \mathrm{~mL}, 0.2 \mathrm{M}, \mathrm{pH} 6.6)$ and potassium ferricyanide $(2.5 \mathrm{~mL}, 1 \%)$. The mixture was then incubated at $50^{\circ} \mathrm{C}$ for 20 min. Next, $2.5 \mathrm{~mL}$ of $10 \%$ trichloroacetic acid was added, which was then centrifuged at $3000 \mathrm{rpm}$ for 10 min. The upper layer of the solution $(2.5 \mathrm{~mL})$ was mixed with distilled water $(2.5 \mathrm{~mL})$ and $\mathrm{FeCl}_{3}(0.5 \mathrm{~mL}, 0.1 \%)$ and the absorbance was measured at $700 \mathrm{~nm}$. Increased absorbance of the reaction mixture indicated increased reducing power. Ascorbic acid was used as standard and test was run in triplicate and results averaged. ${ }^{37}$ 


\section{Hydroxyl Radical Scavenging Activity}

Hydroxyl radical scavenging activity of the leaf fractions was determined according to the method reported by Pavithra and Vadivukkarasi. ${ }^{38}$ Briefly, the reaction mixture contained 1 $\mathrm{mL}$ of different concentrations of these fractions $(100 \mu \mathrm{g} /$ $\mathrm{mL}, 200 \mu \mathrm{g} / \mathrm{mL}, 400 \mu \mathrm{g} / \mathrm{mL}$ and $800 \mu \mathrm{g} / \mathrm{mL}), 1 \mathrm{~mL}$ of ironEDTA solution, $0.5 \mathrm{~mL}$ of $0.018 \%$ EDTA, $1 \mathrm{~mL}$ of DMSO (0.85\% in $0.1 \mathrm{M}$ phosphate buffer $\mathrm{pH} 7.4)$, and $0.5 \mathrm{~mL}$ of $0.22 \%$ ascorbic acid. The tubes were tightly sealed and incubated at $90^{\circ} \mathrm{C}$ for $15 \mathrm{~min}$; the reaction was stopped by adding $1 \mathrm{~mL}$ of ice-cold $17.5 \%$ TCA. Then, $3.0 \mathrm{~mL}$ of Nash reagent mixed with $100 \mathrm{~mL}$ distilled water was added and incubated at room temperature for $15 \mathrm{~min}$ for color development. The absorbance was measured at $412 \mathrm{~nm}$ against a reagent blank. The result was represented in terms of the number of microgram equivalents of ascorbic acid per milligram of plant fraction. ${ }^{38}$ The inhibition percentage hydroxyl radical scavenging was calculated according to the following equation:

$\%$ inhibition $=(\%)=\left[\left(A_{0}-A_{1}\right) / A_{0}\right] \times 100$

where $\mathrm{A}_{0}$ is the absorbance of control reaction and $\mathrm{A}_{1}$ is the absorbance of the sample fractions.

\section{Acute Toxicity Test}

An acute toxicity test $\left(\mathrm{LD}_{50}\right)$ was conducted on female white albino mice. These experiment animals weighed, on average, $35 \mathrm{~g}$ and were 9 weeks old. Prior to experimentation, the mice rested for six days until they adapted to the environment and were in good condition. They were kept in plastic mice cages at a temperature of $22^{\circ} \mathrm{C}$ and exposed to a normal light-dark cycle with ad libitum pellet feed and water. $^{22}$ This study was done using the limit test dose of $2000 \mathrm{mg} / \mathrm{kg}$ as recommended by the Organization for Economic Cooperation and Development (OECD) guideline. ${ }^{39}$ The white albino mice were randomly distributed into seven groups $(n=3)$. The first three groups received a $2000 \mathrm{mg} / \mathrm{kg}$ fraction of the leaf part of C. aurea in a single dose. The last group (negative control group) received a placebo (distilled water $10 \mathrm{~m} 1 / \mathrm{kg}$ ). The mice were inspected frequently for the first $4 \mathrm{hrs}$ after administration, for frequent urination, signs of intoxication, and neurological signs. Then, we followed the mice for 14 days for gross behavioral changes and other signs of toxicity.

\section{Ethical Approval}

All experimental mice were kept on standard mice feed and water was provided ad libitum and experimentation was conducted in accordance with the University of Gondar, Research and Community Service Vice President's Office. Ethical clearance with approval (No. O/V/P/RC/05/813) was obtained from the Research and Community Service Vice President's Office, University of Gondar, before the commencement of the study. All animal experiments were conducted in accordance with the National Institutes of Health Guide for the Care and Use of Laboratory Animals (NIH Publications No. 8023, 8th edition).

\section{Data Management and Analysis}

Data collected from each study plant and the laboratory results were entered on a Microsoft Excel spreadsheet. The data was represented as mean $\pm \mathrm{SE}$ and statistical significance was carried out employing one-way analysis of variance (ANOVA) in SPSS followed by the Tukey post hoc test where $\mathrm{p}<0.005$ was considered statistically significant. Correlations were determined using the Pearson correlation coefficient in bivariate correlations. Ps of $<0.05$ were regarded as significant.

\section{Results}

\section{Screening of Phytochemical}

The results of the phytochemical screening of the leaves of C. aurea are shown in Table 1.

\section{Antibacterial Activities Agar Well Diffusion}

The growth of pathogenic bacterial strainss was inhibited by the EA, DCM, and n-hexane fractions of the leaves of $C$. aurea. Among the pathogenic bacteria, the most susceptible bacterium at $500 \mathrm{mg} /$ well was $E$. faecalis and $S$. typhi in an ethyl acetate fraction of $C$. aurea (Tables 2, Tables 3-4). The mean zones of inhibition of

Table I Phytochemical Analysis of the Leaf Fractions of $C$. aurea

\begin{tabular}{|l|l|l|l|}
\hline & EA & DCM & NH \\
\hline Tannins & + & + & + \\
Saponins & + & + & + \\
Cardiac glycoside & - & - & - \\
Flavonoids & + & + & + \\
Steroids & + & + & + \\
Terpenoids & + & + & + \\
Phenols & + & + & + \\
Anthraquinone & - & - & - \\
Alkaloids & + & + & + \\
\hline
\end{tabular}

Note: $+=$ present, $-=$ absent.

Abbreviations: EA, ethyl acetate; $\mathrm{NH}$, n-hexane; DCM, dichloromethane. 
Table 2 Zone of Inhibition (in $\mathrm{mm}$ ) of EA Fraction of the Leaves of $C$. aurea

\begin{tabular}{|c|c|c|c|c|c|c|}
\hline & \multicolumn{6}{|l|}{ Ethyl Acetate } \\
\hline & $500 \mathrm{mg} / \mathrm{mL}$ & $250 \mathrm{mg} / \mathrm{mL}$ & $125 \mathrm{mg} / \mathrm{mL}$ & $62.5 \mathrm{mg} / \mathrm{mL}$ & Gen & CPR \\
\hline $\begin{array}{l}\text { C. freundii (ATCC } \\
43864 \text { ) }\end{array}$ & 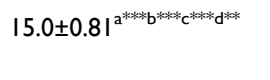 & 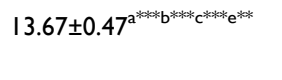 & $12 \pm 0.81^{\mathrm{a}^{* * * * * * * * * * * * * *}}$ & 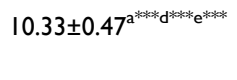 & $22 \pm 1.41$ & $25 \pm 0.81$ \\
\hline $\begin{array}{l}\text { K. pneumonia (ATCC } \\
700603 \text { ) }\end{array}$ & 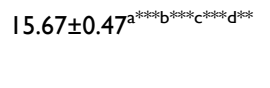 & 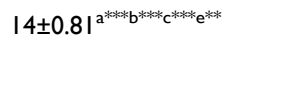 & $10 \pm 0.81^{\mathrm{a}^{* * * * * * * * * *} \mathrm{e}^{* * * *}}$ & $8.33 \pm 0.00^{\mathrm{a} * * * * * * * * * * * * * *}$ & $22 \pm 1.63$ & $23 \pm 1.63$ \\
\hline $\begin{array}{l}\text { E. faecalis (ATCC } \\
292 \mid 2 \text { ) }\end{array}$ & 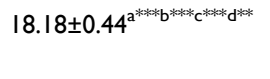 & $16.33 \pm 0.47^{\mathrm{a}^{* * * * *} \mathrm{~b} * * * c^{* * * * *} \mathrm{e}^{* * *}}$ & $12.67 \pm 0.47^{\mathrm{a}^{* * * * *} \mathrm{~d} * * * *} \mathrm{e}^{* * * *}$ & $9.33 \pm 0.47^{\mathrm{a} * * * \mathrm{~d} * * *} \mathrm{e}^{* * * *}$ & $19 \pm 0.00$ & $26.33 \pm 0.47$ \\
\hline S. Typhi (ATCC 6539) & 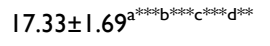 & 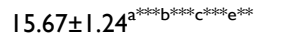 & $14 \pm 0.00^{\mathrm{a}^{* * * * \mathrm{~d}^{*} * * *} \mathrm{e}^{* * * *}}$ & $11.33 \pm 0.00^{\mathrm{ad} * * * \mathrm{e}^{* * * *}}$ & $2 \mathrm{I} \pm 0.8 \mathrm{I}$ & $2 \mathrm{l} \pm 0.8 \mathrm{I}$ \\
\hline E. coli (ATCC 25922)) & $13.67 \pm 0.47^{\mathrm{a}^{* * * *} b * * * * * * * d^{* * *}}$ & $11.33 \pm 0.47^{\mathrm{a}^{* * * * b^{*} * * * * * * * * * * *}}$ & $9.33 \pm 0.47^{\mathrm{a}^{* * * *} \mathrm{~d} * * * \mathrm{e}^{* * * *}}$ & $7.67 \pm 0.00^{\mathrm{a} * * *} \mathrm{~d}^{* * * *} \mathrm{e}^{* * * *}$ & $19 \pm 0.81$ & $22.33 \pm 0.94$ \\
\hline E. coli (Clinical) & 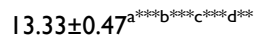 & 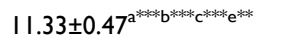 & $9.33 \pm 0.47^{\mathrm{a} * * * \mathrm{~d}^{* * * *} \mathrm{e} * * * *}$ & $7.67 \pm 0.41^{\mathrm{a}^{* * * * *} \mathrm{~d}^{* * * * *} \mathrm{e}^{* * * *}}$ & $|8.67 \pm 0.47|$ & $24.33 \pm 0.47$ \\
\hline $\begin{array}{l}\text { S. aureus (ATCC } \\
29213 \text { ) }\end{array}$ & 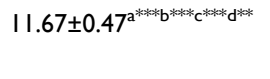 & $\mid 1.67 \pm 0.0 .57^{\mathrm{a} * * * \mathrm{~b} * * * * * * * *} \mathrm{e}^{* * *}$ & $8.67 \pm 0.47^{\mathrm{a} * * *} \mathrm{~d}^{* * * *} \mathrm{e}^{* * * *}$ & $4.67 \pm 3.25^{\mathrm{a} * * * *} \mathrm{~d}^{* * * *} \mathrm{e}^{* * * *}$ & $16.67 \pm$ & $20.67 \pm 1.7$ \\
\hline
\end{tabular}

Notes: Values are expressed as Mean \pm SEM ( $\mathrm{n}=3)$, analysis was performed with one-way ANOVA followed by Tukey's test; ${ }^{\mathrm{a}}$ compared to positive control, ${ }^{\mathrm{b}}$ to $62.5 \mathrm{mg} / \mathrm{mL}$, cto $125 \mathrm{mg} / \mathrm{mL}$, ${ }^{d}$ to $250 \mathrm{mg} / \mathrm{mL}$, ${ }^{\text {e }}$ to $500 \mathrm{mg} / \mathrm{mL}$; $* *$ p $<0.01$, *** $<<0.001$.

Abbreviations: Gen, gentamicin; CPR, ciprofloxacin; DMSO, dimethyl sulfoxide.

Table 3 Zone of Inhibition (in $\mathrm{mm}$ ) of DCM Fraction of the Leaves of $C$. aurea

\begin{tabular}{|c|c|c|c|c|c|c|}
\hline & \multicolumn{6}{|l|}{ Dichloromethane } \\
\hline & $500 \mathrm{mg} / \mathrm{mL}$ & $250 \mathrm{mg} / \mathrm{mL}$ & $125 \mathrm{mg} / \mathrm{mL}$ & $62.5 \mathrm{mg} / \mathrm{mL}$ & Gen. & CPR. \\
\hline K. pneumonia & $|4.4 \pm 0.3|^{\mathrm{a}^{* * *} \mathrm{~b} \mathrm{~b}^{* * * *} \mathrm{c} * * * *} \mathrm{~d}^{* * *}$ & $12.77 \pm 0.39^{a * * *} \mathrm{~b}^{* * * * * * * *} \mathrm{e}^{* * *}$ & $11 \pm 0.58^{\mathrm{a}^{* * * * * \mathrm{~d}^{* * * *} \mathrm{e}} \mathrm{e}^{* * * *}}$ & $9 \pm 0.58^{\mathrm{a}^{* * * *} \mathrm{~d} * * * *} \mathrm{e}^{* * * *}$ & $19.33 \pm 1.2$ & $24.67 \pm 0.88$ \\
\hline Citrobactor & $14 \pm 0.58^{\mathrm{a}^{* * * *} \mathrm{~b}^{* * * *} \mathrm{c} * * * *} \mathrm{~d} * *$ & $12 \pm 0.58^{\mathrm{a}^{* * * *} \mathrm{~b}^{* * * *} \mathrm{c} * * *} \mathrm{e}^{* * *}$ & $10 \pm 0.58^{\mathrm{a}^{* * * *} \mathrm{~d}^{* * * *} \mathrm{e}^{* * * *}}$ & $8.7 \pm 0.35^{\mathrm{a}^{* * * * *} \mathrm{~d} * * * *} \mathrm{e}^{* * * *}$ & $21.33 \pm 0.88$ & $24 \pm 0.58$ \\
\hline E. faecalis & $16 \pm 0.58^{\mathrm{a}^{* * * * b * * * *} \mathrm{c} * * * 2 * *}$ & $14 \pm 0.58^{\mathrm{a}^{* * * *} \mathrm{~b}^{* * * *} \mathrm{c} * * *} \mathrm{e}^{* * *}$ & 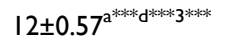 & $10.33 \pm 1.2^{\mathrm{a}^{* * *} \mathrm{~d} * * * * * * * *}$ & $21.5 \pm 0.76$ & $27.43 \pm 0.29$ \\
\hline S. typhi & $15 \pm 0.57^{a^{* * * 6} b^{* * * *} c_{c}^{* * * *} d^{* * *}}$ & $13 \pm 0.57^{\mathrm{a}^{* * * 6} \mathrm{~b} * * * c^{* * * * *} \mathrm{e}^{* * *}}$ & $\mid 1.1 \pm 1.05^{\mathrm{a}^{* * * *} \mathrm{~d} * * * *} \mathrm{e}^{* * * *}$ & $9 \pm 0.57^{\mathrm{a}^{* * * * *} \mathrm{~d} * * * *} \mathrm{e}^{* * * *}$ & $20 \pm 0.58$ & $25.73 \pm 0.37$ \\
\hline E. coli (ATCC). & $13 \pm 0.33 \mathrm{~b} 4^{\mathrm{a}^{* * * * 6 * * * *} \mathrm{c} * * * *} \mathrm{~d} * *$ & $10.7 \pm 0.35^{\mathrm{a} * * * \mathrm{~d} * * * *} \mathrm{e}^{* * * *}$ & $9.1 \pm 0.1^{\mathrm{a} * * * \mathrm{~d} * * * *} \mathrm{e}^{* * * *}$ & $7.17 \pm 0.17^{\mathrm{a} * * * \mathrm{~d}^{* * * *} \mathrm{e} * * * *}$ & $18.33 \pm 0.88$ & $27.67 \pm 0.33$ \\
\hline E. coli clinical & $12.9 \pm 0.58^{\mathrm{a}^{* * * *} \mathrm{~b}^{* * * * *} \mathrm{C}^{* * * *} \mathrm{~d} * *}$ & $10.73 \pm 0.37^{\mathrm{a}^{* * * *} \mathrm{~d} * * * *} \mathrm{e}^{* * * *}$ & $9.1 \pm 0.1^{\mathrm{a}^{* * * *} \mathrm{~d} * * * \mathrm{e}^{* * * *}}$ & $8.13 \pm 0.13^{\mathrm{a} * * * \mathrm{~d} * * * *} \mathrm{e}^{* * *}$ & $19 \pm 0.58$ & $23.33 \pm 1.2$ \\
\hline S. aureus & $10.67 \pm 0.33^{\mathrm{a}^{* * *} \mathrm{~b} * * * *} \mathrm{c} * * * \mathrm{~d}^{* *}$ & $9.4 \pm 0.3 \mathrm{I}^{\mathrm{a} * * * 3 * * *} \mathrm{e}^{* * * *}$ & $8.03 \pm 0.03^{\mathrm{a}^{* * * *} \mathrm{~d} * * * *} \mathrm{e}^{* * *}$ & $6.33 \pm 0.03^{\mathrm{a}^{* * * *} \mathrm{~d} * * * * * * * *}$ & $17 \pm 0.57$ & $21 \pm 0.37$ \\
\hline
\end{tabular}

Notes: Values are expressed as Mean \pm SEM $(n=3)$, analysis was performed with one-way ANOVA followed by Tukey's test; ${ }^{a}$ compared to positive control, ${ }^{b}$ to $62.5 \mathrm{mg} / \mathrm{mL}$, cto $125 \mathrm{mg} / \mathrm{mL}$, ${ }^{d}$ to $250 \mathrm{mg} / \mathrm{mL}$, ${ }^{\text {e }}$ to $500 \mathrm{mg} / \mathrm{mL}$; **p<0.01, ***p $<0.001$.

Abbreviations: Gen, gentamicin; CPR, ciprofloxacin; DMSO, dimethyl sulfoxide.

Table 4 Zone of Inhibition (in $\mathrm{mm}$ ) of $\mathrm{n}$-Hexane Fraction of the Leaves of $C$. aurea

\begin{tabular}{|c|c|c|c|c|c|c|}
\hline \multicolumn{7}{|l|}{ n-Hexane } \\
\hline & $500 \mathrm{mg} / \mathrm{mL}$ & $250 \mathrm{mg} / \mathrm{mL}$ & $125 \mathrm{mg} / \mathrm{mL}$ & $62.5 \mathrm{mg} / \mathrm{mL}$ & Gen. & CPR. \\
\hline C. freundii (ATCC 43864) & 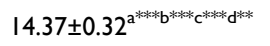 & $14.32 \pm 0.32^{2 * * * * b * * * * * * * * * * * *}$ & $10.37 \pm 0.32^{\mathrm{a}^{* * * * *} \mathrm{~d} * * * * * * * * *}$ & 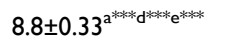 & $18 \pm 0.58$ & $20.67 \pm 1.20$ \\
\hline $\begin{array}{l}\text { K. pneumonia (ATCC } \\
\text { 700603) }\end{array}$ & $13.33 \pm 0.8^{\mathrm{a} * * * \mathrm{~b} * * * * * * * * * \mathrm{~d}^{*} * *}$ & $12.33 \pm 0.88^{\mathrm{a} * * * \mathrm{~b}} \mathrm{~b} * * * * * * * * \mathrm{e}^{* * *}$ & $11 \pm 1.16^{\mathrm{a}^{* * * * * * * * *} \mathrm{e}^{* * * *}}$ & $9 \pm 1.00^{\mathrm{a} * * * \mathrm{~d} * * * *} \mathrm{e}^{* * * *}$ & $20 \pm 1.16$ & $21,67 \pm 1.20$ \\
\hline E. faecalis (ATCC 292।2) & $15.07 \pm 0.8^{\mathrm{a}^{* * *} \mathrm{~b}^{* * * * *} \mathrm{c}^{* * * *} \mathrm{~d}^{* * *}}$ & $13.37 \pm 0.32^{2 * * * * b * * * * * * * * * * * *}$ & $11.33 \pm 0.33^{\mathrm{a}^{* * * *} \mathrm{~d} * * * *} \mathrm{e}^{* * * *}$ & $9.37 \pm 0.32^{\mathrm{a}^{* * * * *} \mathrm{~d}^{* * * * *} \mathrm{e}^{* * * *}}$ & $21.33 \pm 0.67$ & $23.33 \pm 1.45$ \\
\hline S. typhi (ATCC 6539) & $14.33 \pm 0.6^{\mathrm{a} * * * \mathrm{~b}} \mathrm{~b}^{* * * *} \mathrm{c}$ c***d** & $13.7 \pm 0.65^{2 * * * b * * * * * * * * * * *}$ & $11.67 \pm 0.33^{\mathrm{a}^{* * * *} \mathrm{~d} * * * *} \mathrm{e}^{* * * *}$ & $9.67 \pm 0.33^{\mathrm{a}^{* * * *} \mathrm{~d}^{* * *} \mathrm{e}} \mathrm{e}^{* * * *}$ & $19 \pm 0.58$ & $22.33 \pm 0.67$ \\
\hline E. coli (ATCC 25922)) & $12.67 \pm 0.33^{\mathrm{a}^{* * * *} b * * * * * * * * * *}$ & $11 \pm 0.58^{\mathrm{a}^{* * * *} \mathrm{~d} * * * *} \mathrm{e}^{* * * * *}$ & $9.37 \pm 0.32^{\mathrm{a}^{* * * *} \mathrm{~d} * * * *} \mathrm{e}^{* * * *}$ & $7.67 \pm 0.33^{\mathrm{a}^{* * * *} \mathrm{~d} * * *} \mathrm{e}^{* * * *}$ & $16 \pm 0.58$ & $19 \pm 0.58$ \\
\hline E. coli (Clinical) & 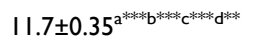 & $10 \pm 0.0^{a^{* * * *} \mathrm{~d} * * * *} \mathrm{e}^{* * * *}$ & $9 \pm 1.0^{\mathrm{a}^{* * * * \mathrm{~d}^{*} * *} \mathrm{e}}$ & $7.7 \pm 0.68^{\mathrm{a}^{* * * * d^{*} * * *} \mathrm{e}^{* * * *}}$ & $16 \pm 0.58$ & $20 \pm 1.00$ \\
\hline S. aureus (ATCC 29213) & $9.67 \pm 0.33^{\mathrm{a}^{* * *} \mathrm{~b}} \mathrm{~b}^{* * * * c^{* * * *}} \mathrm{~d}^{* * *}$ & $8.1 \pm 0.07^{\mathrm{a}^{* * * * * * * * * *} \mathrm{e}^{* * * * *}}$ & $8.0 \pm 0.33^{\mathrm{a}^{* * * * * * * * * * * * * * *}}$ & $7.37 \pm 0.32^{\mathrm{a}^{* * * * \mathrm{~d}^{*} * * *} \mathrm{e}^{* * * * *}}$ & $14.43 \pm 0.29$ & $17.67 \pm 0.88$ \\
\hline
\end{tabular}

Notes: Values are expressed as Mean \pm SEM ( $n=3$ ), analysis was performed with one-way ANOVA followed by Tukey's test; ${ }^{a}$ compared to positive control, ${ }^{b}$ to $62.5 \mathrm{mg} / \mathrm{mL}$, 'to $125 \mathrm{mg} / \mathrm{mL}$, ${ }^{d}$ to $250 \mathrm{mg} / \mathrm{mL}$, ${ }^{e}$ to $500 \mathrm{mg} / \mathrm{mL}$; $* *{ }^{*}<0.01$, $* * *{ }^{2}<0.001$.

Abbreviations: Gen, gentamicin; CPR, ciprofloxacin; DMSO, dimethyl sulfoxide. 
E. faecalis and S. typhi on C. aurea were $18 \mathrm{~mm}$ and $17.33 \mathrm{~mm}$, respectively. In addition, among the gram negative bacteria, standard strains of E. faecalis were most susceptible at $500 \mathrm{mg} /$ well of these plant fractions and $S$. aureus was less susceptible. Comparisons between the plant fractions and the positive control revealed there were significant differences $(\mathrm{p}<0.001)$. There were statistically significance differences between the antimicrobial activity of the highest concentrations and the preceding concentrations of $E$. coli (standard), E. coli (Clinical), and $S$. aureus $(\mathrm{p}<0.05)$.

\section{Minimum Inhibitory Concentration of Fractions}

Minimum inhibitory concentration (MIC) values ranged from 1.95 to $31.25 \mathrm{mg} / \mathrm{mL}$ for ethyl acetate fraction, 7.81 \pm 0.00 to 31.25 for dichloromethane fraction, and $13.02 \pm 4.51$ $\mathrm{mg} / \mathrm{mL}$ for $\mathrm{n}$-hexane fraction of $C$. aurea leaves.

In $C$. aurea for the ethyl acetate solvent fraction, the maximum MIC obtained was $1.95 \mathrm{mg} / \mathrm{mL}$ (S. typhi), while the minimum MIC was $32.25 \mathrm{mg} / \mathrm{mL}$ (S. aureus). For dichloromethane solvent fraction, the maximum MIC obtained was $7.81 \mathrm{mg} / \mathrm{mL}$ (E. faecalis) and the minimum MIC was $62.5 \mathrm{mg} /$ $\mathrm{mL}$ (E. coli ATCC). For n-hexane fraction the maximum MIC obtained was $13.02 \mathrm{mg} / \mathrm{mL}$ (E. faecalis) and the minimum MIC was $62.5 \mathrm{mg} / \mathrm{mL}$ (E. coli clinically isolated) (Table 5).

\section{Minimum Bactericidal Concentration of Fractions}

Based on the MBC determination method, n-hexane, DCM, and EA fractions of the C. aurea had antibacterial effects. As indicated in Table 5, the corresponding means of MIC value and $\mathrm{MBC}$ value of the fractions were almost different in terms of the growth of the majority of the test bacterial strains. The maximum mean MBC (least dilution) was $1.95 \pm 0.00 \mathrm{mg} / \mathrm{mL}$ (against $S$. typhi) for ethyl acetate fraction, 13.02 \pm 4.51 (against E. faecalis) for dichloromethane fractions, and $15.62 \pm 0.00 \mathrm{mg} / \mathrm{mL}$ (against $E$. faecalis) for nhexane fraction of $C$. aurea. When comparing ceftriaxone (positive control) and plant fractions, ceftriaxone had the higher antimicrobial effect $(\mathrm{p}<0.05)$.

\section{Antioxidant Activity}

\section{Phosphomolybdenum Reduction Assay}

The total antioxidant capacities of $C$. aurea leaf fractions were determined using the phosphomolybdate method. All fractions of these plants possess good antioxidant capacities (see Figure 1). The n-hexane fraction of $C$. aurea possesses antioxidant activity (AAE $2.56 \mu \mathrm{g} / \mathrm{mg}$ ) closely related to the standard antioxidant (ascorbic acid). The dichloromethane and ethyl acetate fractions of $C$. aurea were slightly lower when compared with the standard compound (AAE 2.33 $\mu \mathrm{g} / \mathrm{mg}$ and $1.73 \mu \mathrm{g} / \mathrm{mg}$, respectively). The n-hexane fraction of $C$. aurea displayed higher reducing activity as compared to the ethyl acetate and dichloromethane fractions. The fractions of $C$. aurea were changed molybdenum (VI) to molybdenum (V) and consequent formation of green phosphate complex at acidic $\mathrm{pH}$. The green color was the indicator of the antioxidant activity of the plants.

\section{Reducing Power Assay}

The reducing power of the solvent fractions of $C$. aurea leaves were investigated using the potassium ferricyanide reduction technique. The n-hexane fraction of C. aurea possesses good reducing power ability when compared to dichloromethane and ethyl acetate (Figure $2)$. The reducing power ability of the n-hexane fraction was (AAE $1.25 \mu \mathrm{g} / \mathrm{mg}$ ), which is almost the same as the standard value $(1.27 \mu \mathrm{g} / \mathrm{mg})$. The reducing power abilities of dichloromethane and ethyl acetate were less than the standard values (AAE $0.93 \mu \mathrm{g} / \mathrm{mg}$ and $1.13 \mu \mathrm{g} / \mathrm{mg}$, respectively). In this test, depending on the reducing

Table 5 MIC and MBC $(\mathrm{mg} / \mathrm{mL})$ Value of the Solvent Fractions of the $C$. aurea

\begin{tabular}{|c|c|c|c|c|c|c|}
\hline \multirow[t]{2}{*}{ v } & \multicolumn{2}{|c|}{ Ethyl Acetate } & \multicolumn{2}{|c|}{ Dichloromethane } & \multicolumn{2}{|l|}{ n-Hexane } \\
\hline & MIC & MBC & MIC & MBC & MIC & MBC \\
\hline C. freundii (ATCC 43864) & $15.62 \pm 0.00$ & $15.62 \pm 0.00$ & $20.83 \pm 9.02$ & $26.04 \pm 9.02$ & $31.25 \pm 0.00$ & $52.08 \pm|0.4|$ \\
\hline K. pneumonia (ATCC 700603) & $6.5 I \pm 2.25$ & $7.81 \pm 0.00$ & $15.62 \pm 0.00$ & $20.83 \pm 9.02$ & $31.25 \pm 0.00$ & $41.67 \pm 18.04$ \\
\hline E. faecalis (ATCC 292I2) & $2.60 \pm 1.12$ & $2.60 \pm 1.12$ & $7.8 I \pm 0.00$ & $|3.02 \pm 4.5|$ & $|3.02 \pm 4.5|$ & $15.62 \pm 0.00$ \\
\hline S. Typhi (ATCC 6539) & $1.95 \pm 0.00$ & $1.95 \pm 0.00$ & $26.04 \pm 9.02$ & $31.25 \pm 0.00$ & $14.68 \pm 1.04$ & $52.08 \pm 104$ \\
\hline E. coli (ATCC 25922)) & $|0.42 \pm 4.5|$ & $|3.02 \pm 4.5|$ & $62.5 \pm 0.00$ & $64.5 \pm 0.00$ & $4 I .67 \pm 4.5 \mid$ & $20.83 \pm 9.02$ \\
\hline E. coli (Clinical) & $20.83 \pm 9.02$ & $24.83 \pm 9.02$ & $26.04 \pm 9.02$ & $51.92 \pm 17.89$ & $62.5 \pm 0.00$ & $63.5 \pm 0.00$ \\
\hline S. aureus (ATCC 29213) & $31.25 \pm 0.00$ & $36.25 \pm 0.00$ & $31.25 \pm 0.00$ & $41.67 \pm 18.04$ & $|3.02 \pm 4.5|$ & $62.5 \pm 0.00$ \\
\hline
\end{tabular}

Note: Where ciprofloxacin was used as a positive control. 


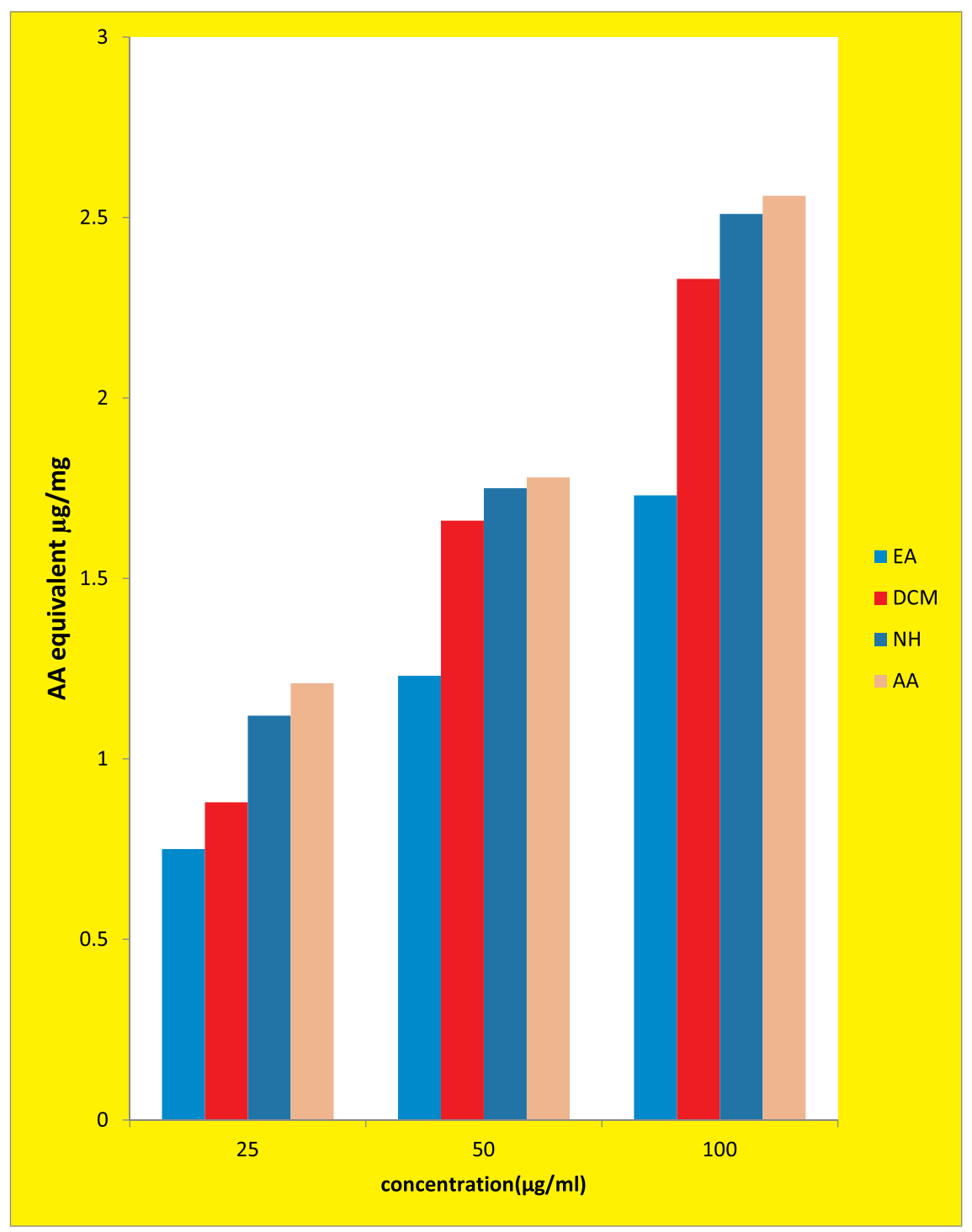

Figure I Phosphomolybdenum reduction assay of the fractions of $C$. aurea leave.

power of each compound, the yellow color of the test mixtures turned to various shades of green and blue. There was an increased reducing power in a dose dependent manner.

\section{Hydroxyl Radical Scavenging Activity}

The solvent fraction of $C$. aurea showed good radical scavenging activity (Figure 3). From the solvent fractions of these plants, the n-hexane fraction of $C$. aurea leaves showed better radical scavenging activity (IC50 $0.12 \mathrm{mg} / \mathrm{mL}$ and $0.46 \mathrm{mg} / \mathrm{mL}$ ), respectively. The hydroxyl radical scavenging activities of ethyl acetate and dichloromethane fractions of $C$. aurea were IC50 $0.61 \mathrm{mg} / \mathrm{mL}$ and $0.52 \mathrm{mg} / \mathrm{mL}$, respectively.

\section{Discussion}

According to this study, solvent fractions of $C$. aurea leave were found to have antimicrobial and antioxidant activity. The highest yield was noted with n-hexane fractions, followed by dichloromethane fractions, then ethyl acetate fractions. The cause might be that solvents with low polarity have the ability to capture a higher amount of nonpolar compounds.

Different fractions of $C$. aurea were evaluated for their antimicrobial effect against certain gram-negative and gram-positive bacteria. The ethyl acetate, dichloromethane, and n-hexane fractions of $C$. aurea leaves had antimicrobial effects on C. freundii, E. coli, K. pneumonia, 


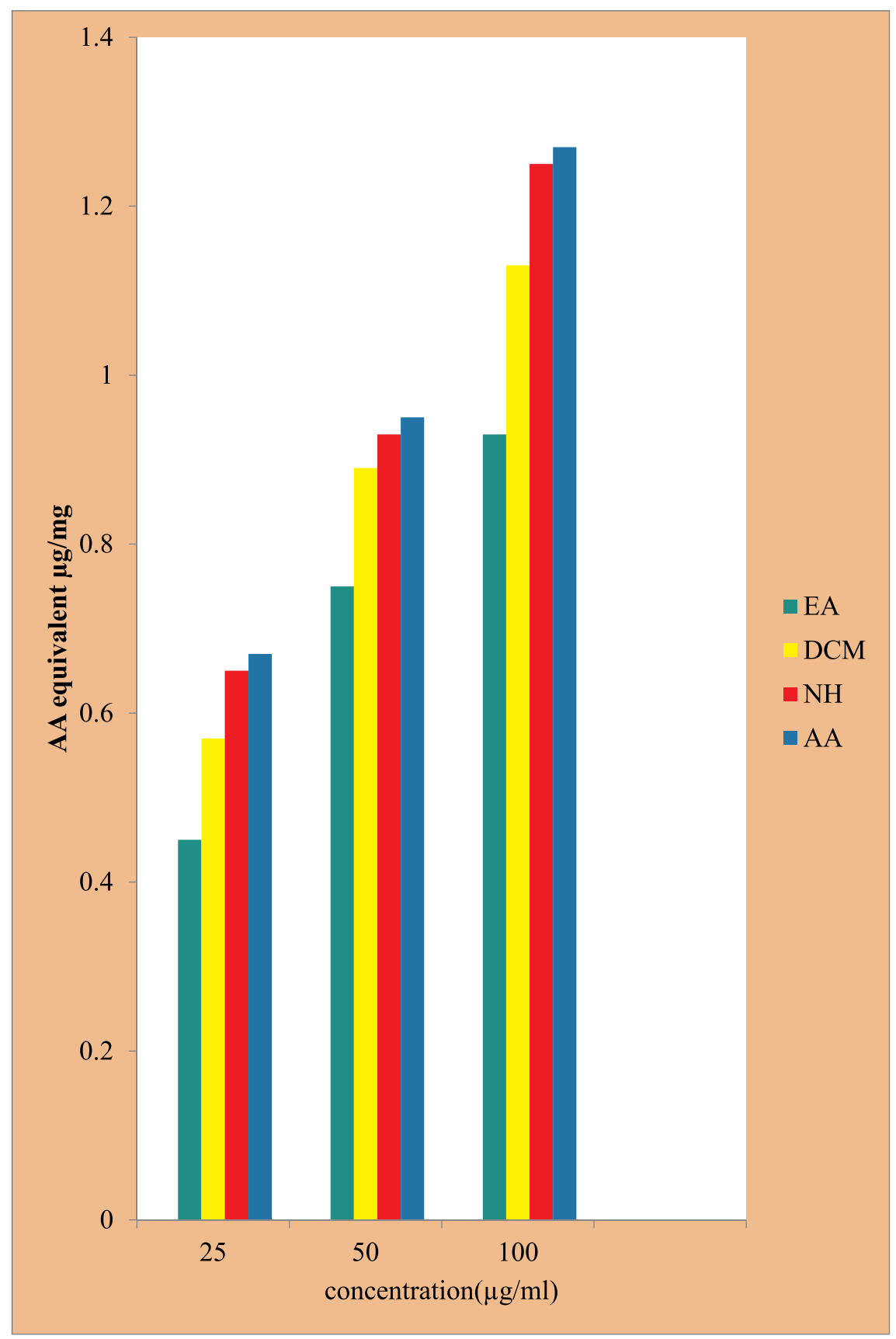

Figure 2 Reducing power of fractions of $C$. aurea leave.

S. typhi, E. faecalis, E. coli (clinically isolated), and $S$. aureus in a varying concentrations.

The possible reason for these differences could be the susceptibility pattern of these bacterial species and the differences in the sites of action of the secondary metabolites identified in each solvent fraction amongst the test bacteria. The analysis showed that there was a highly significant difference $(\mathrm{p}<0.05)$ when the effect of the plant fractions was compared to that of the positive control.
The current study indicated that the solvent fractions of these plants had different effects on the test bacteria. ${ }^{22}$ The cause might be related to their solubility and the capacity of these compounds to pass through the biological membrane. These findings are supported by the reports of Umer et $\mathrm{al}^{22}$ and Adedapo et $\mathrm{al}^{23}$ who observed different effects on different species of bacteria.

According to the qualitative analysis of the solvent fractions, the plants had different secondary 


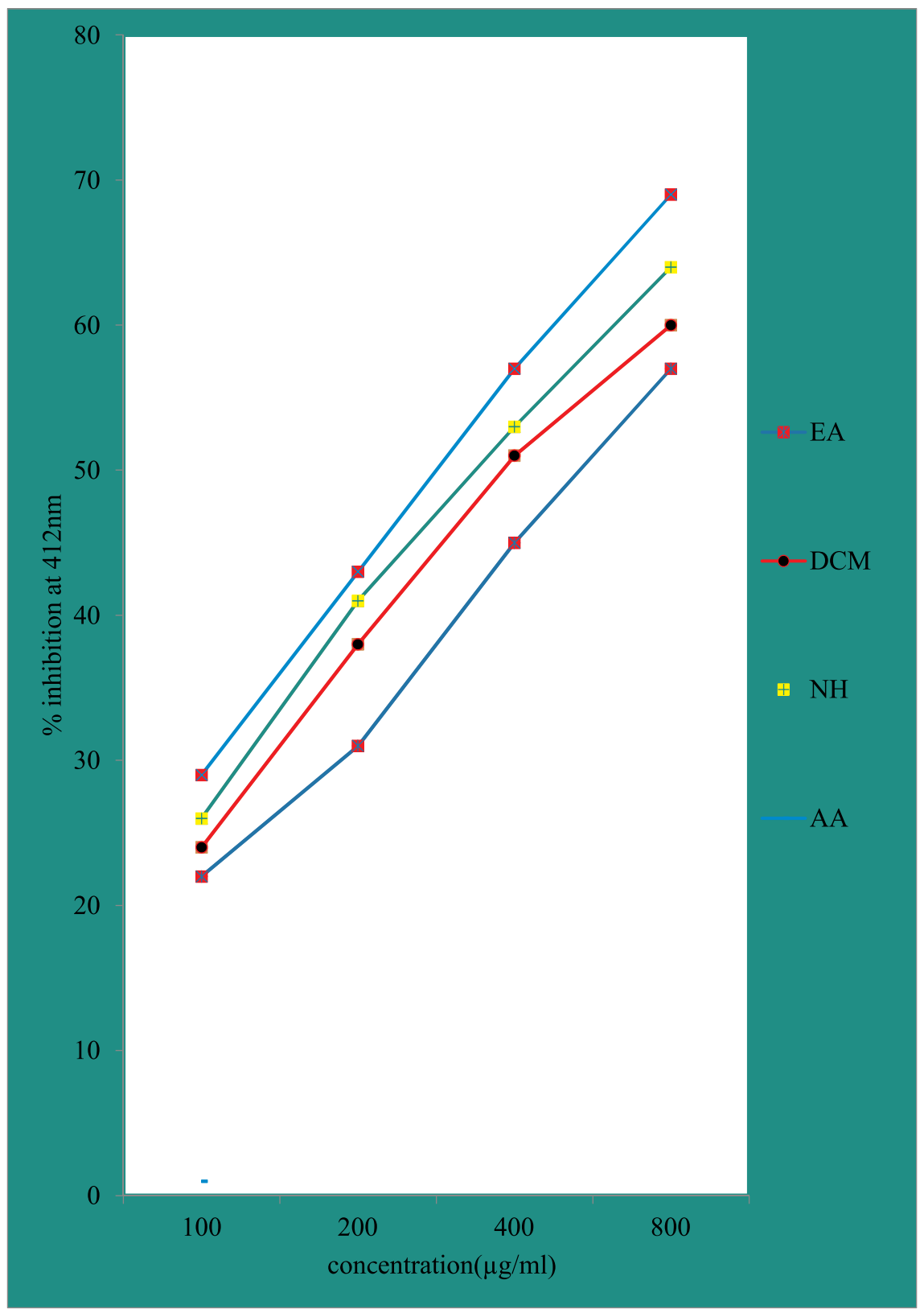

Figure 3 Hydroxyl radical scavenging activity of fractions of $C$. aurea leave.

metabolites. These phytochemicals found in the crude methanol extract and fractions were positive for tannins, saponins, phenol compounds, flavonoids, terpenoids, steroids and alkaloids. This finding was in line with the findings of Umer et $\mathrm{al}^{22}$ and Eyasu et al. ${ }^{24}$ However, cardiac glycosides, as reported by Eyasu et $\mathrm{al}^{24}$ in the crude ethanolic extracts of the leaves of $C$. aurea were not found in the current study. Furthermore, the presence of steroids was not reported by Umer et al. ${ }^{22}$ This difference could be attributed to experimental error and also the methods and solvents used during the extraction procedures.

In the current study, the oral acute toxicity effects of the fractions were safe at $2000 \mathrm{mg} / \mathrm{kg}$. This finding is in line with the previous findings of Umer et $\mathrm{al}^{22}$ and Eyasu et al. ${ }^{24}$

Antioxidant activities of fractions of $C$. aurea were evaluated using hydroxyl radical scavenging, phospho- 
molybdenum reduction assay and reduction power assays. However, in the previous study by Adedapo et $\mathrm{al}^{23}$ the free radical scavenging activity of the leaf extracts of $C$. aurea were determined using 1,1Diphenyl-2-picrylhydrazyl (DPPH), 2,2'-azinobis-3ethylbenzothiazoline-6-sulfonic acid (ABTS), and FRAP assay.

\section{Conclusion}

In the current study, high antioxidant activity was observed in the fractions (dichloromethane, ethyl acetate and n-hexane). The presence of flavonoids and phenolic compounds in the nonpolar fractions of $C$. aurea leaves were responsible for higher antioxidant activity.

Hence, this study supports conventional usage of this therapeutic plant in the management of bacterial contaminations. Further studies aimed at the isolation and characterization of the active compounds in the nonpolar fractions of $C$. aurea leaves could reveal compounds with better therapeutic uses.

\section{Abbreviations}

ATCC, American type culture collection; AAE, ascrobic acid equivalent; CFU, colony forming units; DCM, dichloromethane; DMSO,dimethyl sulfoxide; EA, ethyl acetate; MHA, Mullen Hinton agar; MHB, Mullen Hinton broth; NH, n-hexane; $\mathrm{IC}_{50}$, Inhibitory concentration 50 .

\section{Data Sharing Statement}

All the data is contained in the manuscript.

\section{Consent for Publication}

All authors read and approved the final manuscript.

\section{Acknowledgment}

The authors thank the Ethiopian Public Health Institute (EPHI) and National Animal Health Diagnostic and Investigation Center (NAHDIC) for the kind gift of bacterial strains.

\section{Author Contributions}

DB, AK, MY, EK, MB and MY are substantial contributors to drafting the article and design, acquisition of data, or analysis and interpretation; drafting the article or revising it critically for important intellectual content; gave final approval of the version to be published, agreed to submit to the current journal; and agree to be accountable for all aspects of the work and to be responsible for all facets of the work in certifying that questions related to the truthfulness or uprightness of any part of the work are properly explored and committed.

\section{Funding}

The authors thank University of Gondar, Research and Community service vice president office for its megaprogram.

\section{Disclosure}

The authors reported no conflicts of interest for this work and declare that there is no direct or indirect conflict of interest which may call into question the validity of this study.

\section{References}

1. Gryseels G, Goe MR. Energy Flows on Smallholder Farms in the Ethiopian Highlands. editors, Gryseels G, Michael R. Goe Highlands Programme, ILCA:Ethiopia; 1984.

2. Duguma R. Smallholder livestock production and marketing systems in the Haramaya district, Eastern Ethiopia. Basic Res J Agri Sci Rev. 2013;2:122-129.

3. Admassu B Primary animal healthcare in Ethiopia: the experience so far; 2011. Conference Paper.

4. Lulekal E, Kelbessa E, Bekele T, Yineger H. An ethnobotanical study of medicinal plants in Mana Angetu District, southeastern Ethiopia. $J$ Ethnobiol Ethnomed. 2008;10:1-10.

5. Abebe D. Traditional medicine in Ethiopia: the attempt being made to promote it for effective and better utilization. SINET Ethiop J Sci. 1986;9:61-69.

6. Dagne E Phytochemical studies of Ethiopian medicinal plants. Proceedings of the workshop on the development and utilization of herbal remedies in Ethiopia; 1996.

7. Teklay A, Abera B, Giday M. An ethnobotanical study of medicinal plants used in Kilte Awulaelo District, Tigray Region of Ethiopia. $J$ Ethnobiol Ethnomed. 2013;9(1):65. doi:10.1186/1746-4269-9-65

8. Chekole G, Asfaw Z, Kelbessa E. Ethnobotanical study of medicinal plants in the environs of Tara-gedam and Amba remnant forests of Libo Kemkem District, northwest Ethiopia. J Ethnobiol Ethnomed. 2015;11:1-38. doi:10.1186/1746-4269-11-1

9. Tolossa K, Debela E, Athanasiadou S, Tolera A, Ganga G. Ethnomedicinal study of plants used for treatment of human and livestock ailments by traditional healers in South Omo, Southern. $J$ Ethnobiol Ethnomed. 2013;9(1):32. doi:10.1186/1746-4269-9-32

10. Lulekal E, Asfaw Z, Kelbessa E, Van DP. Ethnoveterinary plants of Ankober District, North Shewa Zone, Amhara Region, Ethiopia. $J$ Ethnobiol Ethnomed. 2014;10(1):21. doi:10.1186/1746-4269-10-21

11. Megersa M, Asfaw Z, Kelbessa E, Beyene A, Woldeab B. An ethnobotanical study of medicinal plants in Wayu Tuka District, East Welega Zone of Oromia. J Ethnobiol Ethnomed. 2013;9(1):68. doi:10.1186/1746-4269-9-68

12. Bekalo TH, Woodmatas SD, Woldemariam ZA. An ethnobotanical study of medicinal plants used by local people in the lowlands of Konta Special Woreda, southern nations, nationalities and peoples regional state, Ethiopia. $J$ Ethnobiol Ethnomed. 2009;5:15. doi:10.1186/1746-4269-5-26

13. Zerabruk S, Yirga G. Traditional knowledge of medicinal plants in Gindeberet district, Western Ethiopia. South Afr J Bot. 2012;78:165169. doi:10.1016/j.sajb.2011.06.006 
14. Teklehaymanot T, Giday M. Ethnobotanical study of medicinal plants used by people in Zegie Peninsula, Northwestern Ethiopia. $J$ Ethnobiol Ethnomed. 2007;11:1-11.

15. Avigdor E, Wohlmuth H, Asfaw Z, Awas T. The current status of knowledge of herbal medicine and medicinal plants in Fiche, Ethiopia The current status of knowledge of herbal medicine and medicinal plants in Fiche, Ethiopia. J Ethnobiol Ethnomed. 2014;10. doi:10.1186/1746-4269-10-38

16. Mesfin F, Demissew S, Teklehaymanot T. An ethnobotanical study of medicinal plants in Wonago Woreda, SNNPR, Ethiopia. J Ethnobiol Ethnomed. 2009;5(1):28. doi:10.1186/1746-4269-5-28

17. Yigezu Y, Haile DB, Ayen WY. Ethnoveterinary medicines in four districts of Jimma zone, Ethiopia: cross sectional survey for plant species and mode of use. J Ethnobiol Ethnomed. 2014;10:1-12. doi:10.1186/1746-4269-10-1

18. Chekole G, Zbinden M, Vogl CR. Ethnobotanical study of medicinal plants used against human ailments in Gubalafto. $J$ Ethnobiol Ethnomed. 2017;13(1):1-29. doi:10.1186/s13002-016-0106-y

19. Abera B. Medicinal plants used in traditional medicine by Oromo people, Ghimbi District, Southwest Ethiopia. J Ethnobiol Ethnomed. 2014;10(1):40. doi:10.1186/1746-4269-10-40

20. Kidane L, Gebremedhin G, Beyene T. Ethnobotanical study of medicinal plants in Ganta Afeshum District, Eastern Zone of. $J$ Ethnobiol Ethnomed. 2018;14(64):1-19. doi:10.1186/s13002-0180266-z

21. Zorloni A, Penzhorn BL, Eloff JN. Extracts of Calpurnia aurea leaves from southern Ethiopia attract and immobilise or kill ticks. Vet Parasitol. 2010;168(1-2):160-164. doi:10.1016/j.vetpar.2009. 10.026

22. Umer S, Tekewe A, Kebede N. Antidiarrhoeal and antimicrobial activity of Calpurnia aurea leaf extract. BMC Complement Altern Med. 2013;13:13. doi:10.1186/1472-6882-13-21

23. Adedapo AA, Jimoh FO, Koduru S, Afolayan AJ, Masika PJ. Antibacterial and antioxidant properties of the methanol extracts of the leaves and stems of Calpurnia aurea. BMC Complement Altern Med. 2008;8(1):53. doi:10.1186/1472-6882-8-53

24. Eyasu M, Shibeshi W, Giday M. In vivo antimalarial activity of hydromethanolic leaf extract of Calpurnia aurea (Fabaceae) in Mice infected with chloroquine sensitive Plasmodium berghei. Int $J$ Pharm Pharmacol. 2013;2(9):131-142.

25. Kaleab. A, Gibbsons W, Phillipson JD, Macsgani P. Alkaloids of Ethiopian Calpurnia aurea. Phytochemistry. 1986;25(6):1443-1447. doi:10.1016/S0031-9422(00)81306-0

26. Kubo I, Matsumoto T, Kozuka M, Chapya A, Naoki H. Quinolizine alkaloids from the African medicinal plant Calpurnia aurea: molluscicidal activity and structural Study by 2D-NMR. Agric Biol Chem. 1984;48(11):2839-2841.

27. Do QD, Angkawijaya AE, Tran-Nguyen PL, et al. Effect of extraction solvent on total phenol content, total flavonoid content, and antioxidant activity of Limnophila aromatica. J Food Drug Anal. 2014;22(3):296-302. doi:10.1016/j.jfda.2013. 11.001
28. Ayoola GA, Coker HA, Adesegun SA. Adepoju-Bello, and A.A. O. $\mathrm{K}$ and EE et al. Phytochemical screening and antioxidant activities of some selected medicinal plants used for malaria therapy in southern Nigeria. Trop J Pharm Res. 2008;7:10191024.

29. Farhan H, Rammal H, Hijazi A, Hamad H, Badran B. Phytochemical screening and extraction of polyphenol from stems and leaves of a Lebanese Euphorbia macrolada schzoceras Bioss. Ann Bol Res. 2012;3:149-156.

30. Molla Y, Nedi T, Tadesse G, Alemayehu H, Shibeshi W. Evaluation of the in vitro antibacterial activity of the solvent fractions of the leaves of Rhamnus prinoides L'Herit (Rhamnaceae) against pathogenic bacteria. BMC Complement Altern Med. 2016;16(1):1-9. doi:10.1186/s12906-016-1279-6

31. Miyasaki Y, Nichols WS, Morgan MA, et al. Screening of herbal extracts against multi-drug resistant Acinetobacter baumannii. Phyther Res. 2010;24(8):1202-1206. doi:10.1002/ptr.3113

32. Bertanha CS, Utrera SH, Gimenez VM, Groppo M, Silva ML, Cunha WR. Antibacterial evaluation of Styraxpohlii and isolated compounds. Braz J Pharm Sci. 2013;49(4):654-658. doi:10.1590/ S1984-82502013000400004

33. CLSI. Methods for Dilution Antimicrobial Susceptibility Tests for Bacteria That Grow Aerobically. 9th ed. USA: CLSI; 2012:12-19. Approved standard. M07-A9 document.

34. Shalayel MHF, Asaad AM, Qureshi MA, Elhussein AB. Anti-bacterial activity of peppermint (Mentha piperita) extracts against some emerging multi-drug resistant human bacterial pathogens. J Herb Med. 2017;7:27-30. doi:10.1016/j.hermed.2016.08.003

35. Andrews JM. Determination of minimum inhibitory concentrations. $J$ Antimic Chemother. 2001;48(suppl_1):5-16. doi:10.1093/jac/48. suppl_1.5

36. Snoussi M, Trabelsi N, Dehmeni A, et al. Phytochemical analysis, antimicrobial and antioxidant activities of Allium roseum var. odoratissimum (Desf.) Coss extracts. Ind Crops Prod. 2016;89:533-542. doi:10.1016/j.indcrop.2016.05.048

37. Boulekbache-Makhlouf L, Medouni L, Medouni-Adrar S, Arkoub L, Madani K. Effect of solvents extraction on phenolic content and antioxidant activity of the byproduct of eggplant. Ind Crops Prod. 2013;49:668-674. doi:10.1016/j.indcrop.2013.06.009

38. Pavithra K, Vadivukkarasi S. Evaluation of free radical scavenging activity of various extracts of leaves from Kedrostis foetidissima (Jacq.) Cogn. Food Sci Hum Well. 2015;4(1):42-46. doi:10.1016/j. fshw.2015.02.001

39. OECD. Guidelines for testing of chemicals acute oral toxicity; 2001 Organization for Economic cooperation and development. OECD.425.

40. The animal welfare act. 2009. Available from: https:/www.regjeringen. no/en/dokumenter/animal-welfare-act/id571188/. Accessed April 22, 2021
The Journal of Experimental Pharmacology is an international, peerreviewed, open access journal publishing original research, reports, reviews and commentaries on all areas of laboratory and experimental pharmacology. The manuscript management system is completely online and includes a very quick and fair peer-review system. Visit http://www.dovepress.com/testimonials.php to read real quotes from published authors. 